\title{
SPRAY ADJUVANT CHARACTERISTICS AFFECTING AGRICULTURAL SPRAYING DRIFT
}

Doi:http://dx.doi.org/10.1590/1809-4430-Eng.Agric.v35n 1p 109-116/2015

\section{RONE B. DE OLIVEIRA ${ }^{1}$, ULISSES R. ANTUNIASSI ${ }^{2}$, MARCO A. GANDOLFO ${ }^{3}$}

\begin{abstract}
This study defined the main adjuvant characteristics that may influence or help to understand drift formation process in the agricultural spraying. It was evaluated 33 aqueous solutions from combinations of various adjuvants and concentrations. Then, drifting was quantified by means of wind tunnel; and variables such as percentage of droplets smaller than $50 \mu \mathrm{m}$ (V50), $100 \mu \mathrm{m}$ (V100), diameter of mean volume (DMV), droplet diameter composing 10\% of the sprayed volume $\left(\mathrm{DV}_{0.1}\right)$, viscosity, density and surface tension. Assays were performed in triplicate, using Teejet XR8003 flat fan nozzles at $200 \mathrm{kPa}$ (medium size droplets). Spray solutions were stained with Brilliant Blue Dye at $0.6 \%(\mathrm{~m} / \mathrm{v})$. DMV, V100, viscosity cause most influence on drift hazardous. Adjuvant characteristics and respective methods of evaluation have applicability in drift risk by agricultural spray adjuvants.
\end{abstract}

KEYWORDS: droplet size, wind tunnel, experimental methods, correlations, multivariate analysis.

\section{CARACTERÍSTICAS DOS ADJUVANTES QUE INFLUENCIAM NA DERIVA DE PULVERIZAÇÕES AGRÍCOLAS}

\begin{abstract}
RESUMO: Neste estudo, foram definidas as principais características dos adjuvantes que influenciam e que podem contribuir para compreender o processo de formação de deriva nas pulverizações agrícolas. $\mathrm{O}$ experimento avaliou a pulverização de 33 soluções aquosas obtidas das combinações de adjuvantes e concentrações, e quantificou dos mesmos a deriva em túnel de vento e as variáveis denominadas de percentual de gotas menores que $50 \mu \mathrm{m}$ (V50), percentual de gotas menores que $100 \mu \mathrm{m}$ (V100), diâmetro mediano volumétrico (DMV), diâmetro de gota tal que 10\% do volume do líquido pulverizado é constituído de gotas de tamanho menor que esse valor $\left(\mathrm{DV}_{0,1}\right)$, viscosidade, densidade e tensão superficial. Os ensaios foram realizados em triplicatas, com pontas de pulverização Tejeet XR8003 VK, pressão de $200 \mathrm{kPa}$ (gotas médias). As soluções pulverizadas foram marcadas com o corante Azul Brilhante a 0,6\% ( $\left.\mathrm{m} \mathrm{v}^{-1}\right)$. O DMV, V100 e a viscosidade causam maior influência no potencial risco de deriva. As características avaliadas e suas respectivas metodologias de determinação apresentam aplicabilidade na avaliação de adjuvantes quanto ao potencial risco de deriva.
\end{abstract}

PALAVRAS-CHAVE: tamanho de gotas, túnel de vento, métodos experimentais, correlações, análise multivariada.

\section{INTRODUCTION}

Adjuvants are products added to the spray solution with specific functions. Activator adjuvants directly improve pesticide efficiency increasing plant absorption rate. Special purpose adjuvants reduce drift negative effects, without acting directly on pesticide efficiency (HAZEN, 2000; McMULLAN, 2000; PENNER, 2000). Previous studies with products other than Brazilian ones have shown physical properties changes in spray and reduced drift risk by adjuvant addition. BECK et al. (2013) found increased effective foliar application of entomopathogenic nematodes

\footnotetext{
${ }^{1}$ Eng $^{\circ}$ A grônomo, Prof. Doutor, Departamento de Engenharia Rural, Universidade Estadual do Norte do Paraná-UENP/Bandeirantes - PR, Fone: (43) 3542-8046, rone@uenp.edu.br.

${ }^{2}$ Eng $^{\mathrm{o}}$ A grônomo, Prof. Doutor, Departamento de Engenharia Rural, Faculdade de Ciênci as Agronômicas-FCA/UNESP/Botucatu SP, ulisses@fca.unesp.br.

${ }^{3}$ Eng $^{\circ}$ A grônomo, Prof. Doutor, Departamento de Engenharia Rural, Universidade Estadual do Norte do Paraná-UENP/Bandeirantes -PR, gandolfo@uenp.edu.br.
} 
with adjuvant and spray nozzle combinations. These effects were confirmed both in experiments in which drift was measured by wind tunnels and directly in the field (OLIVEIRA et al., 2013). Potential drift risk have been satisfactory estimated by means of wind tunnel method (MOREIRA JÚNIOR \& ANTUNIASSI, 2010). Although real drift conditions might only be obtained in field experiments, the wind tunnel experiments have a great advantage over those, once wind tunnels determine the potential drift risk of different application systems. These experiments could not be repeated and compared under field conditions due to weather variations (NUYTTENS et al., 2009; CHECHETTO et al, 2013; GANDOLFO et al., 2013; FRITZ et al., 2014; GANDOLFO et al., 2014).

Droplet spectrum has been recognized as the most important variable to be controlled to reduce spraying drifts, especially in aerial applications. Spraying produces drops of different sizes and, therefore, it is required technical criteria to analyze and quantify comparing droplet sizes produced by other equipment. Thus, many researchers have used the laser diffraction method to study and analyze the droplet spectrum of different equipment (MOTA et al., 2010; CHECHETTO et al. 2013; BUENO et al., 2013; OLIVEIRA et al., 2013).

The present study aimed to define the main adjuvant characteristics that influence and might contribute to understand drift formation process during agricultural spraying.

\section{MATERIAL AND METHODS}

The experiment was performed by spraying 33 aqueous solution of 18 adjuvant types at different doses and drift measurements were made by means of the wind tunnel under controlled conditions (Table 1). Adjuvants were chosen by their market acceptability at manufacturer recommended doses or simulating field conditions. These products belong to surfactant, mineral and vegetal oil and drift reducers, representing the commonly used functional groups of adjuvants in Brazil (Table 1). The water used in the experiment was distilled and had a surface tension of $72.6 \mathrm{mN} \mathrm{m}^{-1}$.

Drift assays were performed by means of designed wind tunnel, which was developed and validated by MOREIRA JÚNIOR \& ANTUNIASSI (2010). The tunnel has an open circuit and a $4.8-\mathrm{m}$-long closed test section, with a square test section of $0.56 \mathrm{~m} \times 0.56 \mathrm{~m}\left(0.31 \mathrm{~m}^{2}\right)$ in $2.5 \mathrm{~m}$ useful length. The device is made of wood and produces a uniform and laminar airflow of $2.0 \mathrm{~m} \mathrm{~s}^{-1}$, generated by a fan with a $180 \mathrm{~W}$ power engine. After formulated, solutions were placed in a $15-\mathrm{L}$ stainless steel tank for storage and $\mathrm{CO}_{2}$ pressurization by compressed gas cylinder. In addition, it was installed an anti-drip valve nozzle and a Teejet XR8003 VK nozzle to generate a jet perpendicular to the tunnel length, subjected to $200 \mathrm{kPa}$ pressure, forming medium sized droplets. All solutions were stained with Brilliant Blue Dye at $0.6 \%(\mathrm{v} / \mathrm{m})$. To collect spray water deposit, polyethylene yarns with $2.0 \mathrm{~mm}$ in diameter and $0.56 \mathrm{~m}$ effective length (wind tunnel width) were used; these yarns were horizontally and perpendicularly placed to the tunnel length through wall holes and fixed by clamps. Polystyrene yarns were positioned at $1.0 ; 1.5 ; 2.0$ to $2.5 \mathrm{~m}$ distant from spray nozzle along the tunnel length. At all points, yarns were fixed at 0.10 and $0.20 \mathrm{~m}$ high from tunnel floor. The environmental conditions were monitored and assays were only carried out under temperatures higher than $30{ }^{\circ} \mathrm{C}$ and $50 \%$ relative humidity. The wind tunnel test method was as described by MOREIRA JÚNIOR \& ANTUNIASSI (2010). 
TABLE 1. Evaluated treatments, main component chemical composition and concentration.

\begin{tabular}{|c|c|c|}
\hline Treatments $^{1 /}$ & Main Component & Concentration $\left(\mathrm{v} \mathrm{v}^{-1}\right.$ and $\left.\mathrm{m} \mathrm{v}^{-1}\right)$ \\
\hline T1-Water & Distilled water & $100 \%$ \\
\hline $\begin{array}{l}\text { T2 and T3- } \\
\text { AgBem }{ }^{\circ}\end{array}$ & Synthetic emulsified resin $387 \mathrm{~g} \mathrm{~L}^{-1}$; Anionic surfactant $129 \mathrm{~g} \mathrm{~L}^{-1}$ & $0.05 \%$ and $0.10 \%$ \\
\hline T4 and T5 - Agral® & Nonylphenoxypoly Ethanol $200 \mathrm{~g} \mathrm{~L}^{-1}$ & $0.10 \%$ and $0.20 \%$ \\
\hline T6 - Agrex Oil® & Fatty acid esters and glycerol $930 \mathrm{~mL} \mathrm{~L}^{-1}$ & $10.00 \%$ \\
\hline T7 - Agro’ óleo $\AA$ & Fatty acid esters $892 \mathrm{~g} \mathrm{~L}^{-1}$ & $5.00 \%$ \\
\hline $\begin{array}{l}\text { T8 and T9 - } \\
\text { Antideriva }{ }^{\circledR}\end{array}$ & Nonylphenol ethoxylate & $0.05 \%$ and $0.10 \%$ \\
\hline T10 - Break Thru® & Polyether-poly methyl-silo xane copolymer $100 \%$ & $0.10 \%$ \\
\hline $\begin{array}{l}\text { T11 and T12 - } \\
\text { Define }{ }^{\circledR}\end{array}$ & Vegetal poly mer & $0.06 \%$ and $0.12 \%$ \\
\hline $\begin{array}{l}\text { T13, T14 and T15 - } \\
\text { Grip® }\end{array}$ & $\begin{array}{l}\text { Synthetic latex and organosilicone surfactant fluid } 450 \mathrm{~g} \mathrm{~L}^{-1} \\
\text { Primary aliphatic oxyalkylated alcohol } 100 \mathrm{~g} \mathrm{~L}^{-1}\end{array}$ & $0.165 \%, 0.30$ and $0.60 \%$ \\
\hline T16 - Haiten $®$ & Polyo xyethylene alkylphenol ether $200 \mathrm{~g} \mathrm{~L}^{-1}$ & $0.10 \%$ \\
\hline $\begin{array}{l}\text { T17 and T18 - In- } \\
\text { Tec® }\end{array}$ & Nonylphenol ethoxylate $124.4 \mathrm{~g} \mathrm{~L}^{-1}$ & $0.05 \%$ and $0.10 \%$ \\
\hline T19 - Joint Oil@ & Aliphatic and aro matic hydrocarbons $761 \mathrm{~g} \mathrm{~L}^{-1}$ & $0.10 \%$ \\
\hline $\begin{array}{l}\text { T20 and T21 - } \\
\text { Li700® }\end{array}$ & Mix of phosphatidylcholine and propionic acid $712.88 \mathrm{~g} \mathrm{~L}^{-1}$ & $0.50 \%$ and $1.0 \%$ \\
\hline $\begin{array}{l}\text { T22 - Li700®+ } \\
\text { Nimbus } ®\end{array}$ & $\begin{array}{l}\text { Aliphatic hydrocarbons } 428 \mathrm{~g} \mathrm{~L}^{-1}+\text { Mix of phosphatidylcholine and } \\
\text { propionic acid } 712.88 \mathrm{~g} \mathrm{~L}^{-1}\end{array}$ & $0.25 \%$ \\
\hline $\begin{array}{l}\text { T23 and T24 - } \\
\text { Nimbus }{ }^{\circledR}\end{array}$ & Aliphatic hydrocarbons $428 \mathrm{~g} \mathrm{~L}^{-1}$ & $0.50 \%$ and $1.0 \%$ \\
\hline $\begin{array}{l}\text { T25 and T26- } \\
\text { Nutrifix }{ }^{\circledR} \\
\end{array}$ & $\begin{array}{l}\text { Sodiu m dodecylbenzene sulphonate } 30 \mathrm{~g} \mathrm{~L}^{-1} ; \\
\text { Carbo xy methylcellu lose } 30 \mathrm{~g} \mathrm{~L}^{-1}\end{array}$ & $0.05 \%$ and $0.10 \%$ \\
\hline $\begin{array}{l}\text { T27 and T28 - } \\
\text { Silwet } \AA\end{array}$ & Polyester Copoly mer and silicone $1000 \mathrm{~g} \mathrm{~L}^{-1}$ & $0.10 \%$ and $0.20 \%$ \\
\hline $\begin{array}{l}\text { T29 and T30 - } \\
\text { TA35® }\end{array}$ & Sodiu m lauryl ether sulfate, surfactants and builders & $0.06 \%$ and $0.20 \%$ \\
\hline $\begin{array}{l}\text { T31 and T32 - Tac- } \\
\text { Tic }{ }^{\circ}\end{array}$ & $\begin{array}{l}\text { Synthetic latex and organosilicone surfactant fluid } 450 \mathrm{~g} \mathrm{~L}^{-1} \\
\text { Primary aliphatic oxyalkylated alcohol } 100 \mathrm{~g} \mathrm{~L}^{-1}\end{array}$ & $0.13 \%$ and $0.26 \%$ \\
\hline T33 - Veget Oil® & Fatty acid esters $930 \mathrm{~g} \mathrm{~L}^{-1}$ and Emu lsifier $70 \mathrm{~g} \mathrm{~L}^{-1}$ & $1.00 \%$ \\
\hline
\end{tabular}

Droplet spectrum analyzes were performed using a drop analyzer in real time based on laser diffraction technique (Mastersizer $S \AA$, version 2.15). This analysis quantifies variables such as DMV, droplet diameter that composes $50 \%$ of the spray volume; $\mathrm{DV}_{0.1}$, droplet diameter of $10 \%$ of the spray volume; part of the spray volume composed by droplets with diameter smaller than $50 \mu \mathrm{m}$ (V50) and the part that comprise droplet sizes greater than $100 \mu \mathrm{m}(\mathrm{V} 100)$.

A Brookfield LVDV-III + viscometer measured solution viscosity. This instrument is equipped with different diameter cylinders (spindles), which are adequate to fluid viscosity. For this research, a cylinder of 100-mm external diameter (spindle \# S-28) at 60-rpm rotation as recommended by manufacturer.

Solution density was assessed by weighing a 1-L solution deposited in a volumetric flask in a 0.01 -g precision scale.

Solution surface tension was determined by gravimetric method by weighing sets of 25 drops per replicate (four replicates), using an analytical balance accurate to $0.1 \mathrm{mg}$, an approximate average time of 27 seconds. Drops were placed into a beaker placed on the scale. They were obtained with the help of a $5 \mathrm{ml}$ syringe and a capillary (used in chromatography), which allowed horizontal position at a predetermined constant speed, increasing droplet uniformity. Droplet weight data were converted to surface tension, assuming an average drop weight of distilled water near $0.0726 \mathrm{~m} \mathrm{~N}^{-1}$.

The experiment was performed in triplicate. Data normality was analyzed by Shapiro-Wilk test $(\mathrm{p}<0.05)$. Moreover, Pearson correlations $(\mathrm{P}<0.01)$ were made to verify the relationship 
between drift and other variables. Finally, multivariate analysis was applied to treat all variables simultaneously, summarizing the data and showing its structure to avoid loss of information.

\section{RESULTS AND DISCUSSION}

Correlation significant results between drift and physical parameters and the droplet spectrum ( $p<0.01)$ are shown in Figure 1. In brief, it appears that the drift is more influenced by inversely proportional variables. Surface tension has not showed significant correlation with drifting. The greatest correlation was in DMV (-0.59), followed by $\mathrm{DV}_{0.1}(\mathrm{r}=-0.49)$, density $(\mathrm{r}=-0.47)$ and viscosity $(r=-0.46)$. Positive correlation was only observed between drift and V100 $(r=0.46)$. Such results highlight spray solution viscosity as an anti-drift agent, notably on basis of viscosity correlation with DMV and V100, using method of adjuvant evaluation regarding drift potential risk (Table 2). This correlation gradient supports the idea that adjuvant addition raises droplet sizes; moreover, spray formation comes from interaction between nozzle model and fluid properties (SPANOGHE et al, 2007). In this research, there was significant correlation between drift and liquid viscosity, and it was assessed that viscosity increases provided drift reduction.

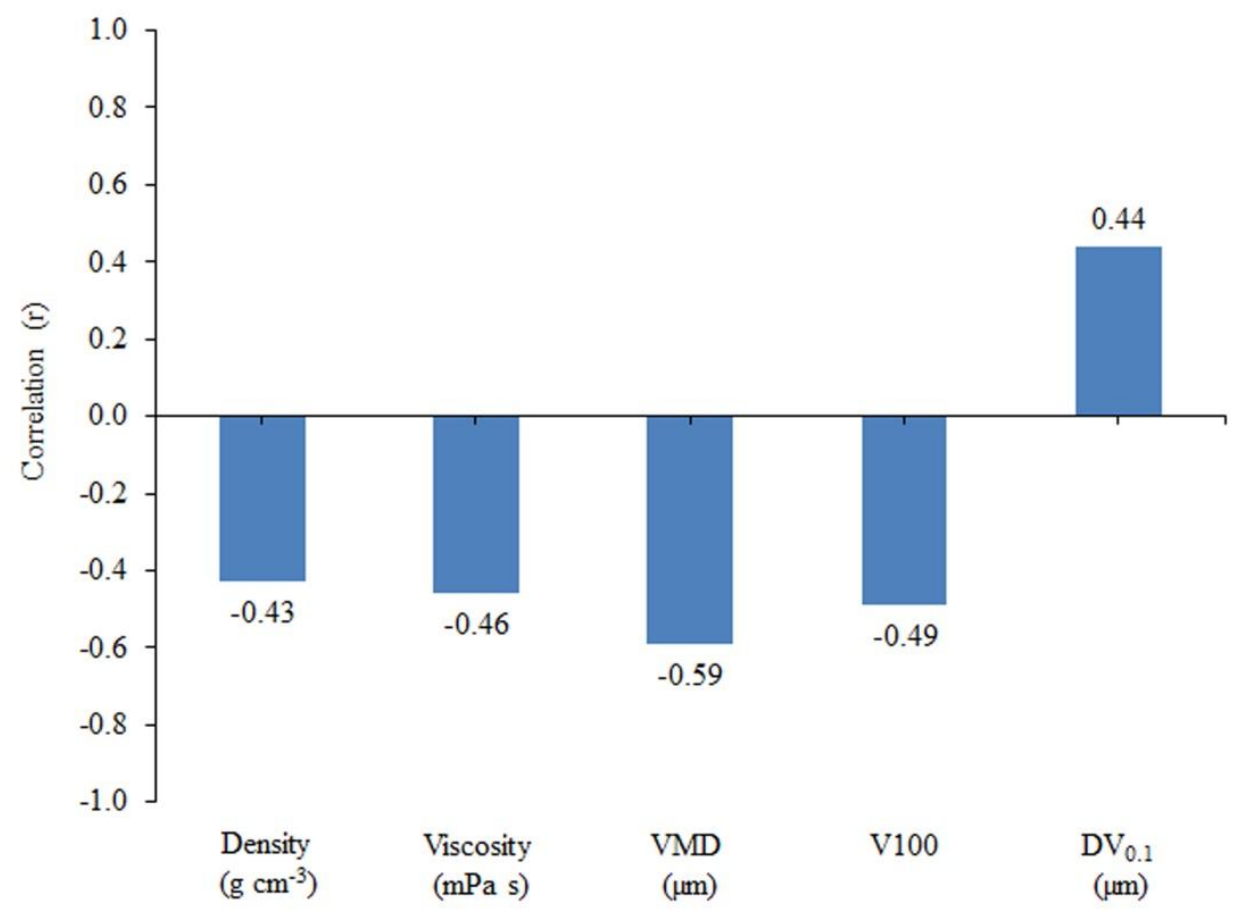

FIGURE 1. Drift general correlation $(\%)$ with significant physical variables $(\mathrm{p}<0.01)$, for all treatments (adjuvant types and concentrations).

Table 2 presents the correlations among physical variables and droplet spectrum. The greatest correlation was between DMV and $\mathrm{DV}_{0.1}(\mathrm{r}=0.86)$; which indicates that a droplet spectrum with larger $\mathrm{DV}_{0.1}$ has also larger DMV. Viscosity and DMV had a directly proportional correlation $(\mathrm{r}=$ 0.67). Raise on spray liquid viscosity increase DMV and, consequently, reducing droplet sizes that are prone to drift (SPANOGHE et al., 2007). It is noteworthy that greater viscosity generates larger droplets, this way acting in drift potential (Table 2 and Figure 1). By adding polymer-based adjuvants, drift was significantly decreased due to increased spray viscosity. Liquid viscosity affects the formation of smaller droplets by resistance to airflow due to extensional viscosity modifying the spray liquid in the tank (SCHAMPHELEIRE et al., 2008).

Inversely and significant proportional correlations occurred between V50 and DMV ( $\mathrm{r}=$ $0.26)$, viscosity $(r=-0.21)$, surface tension $(r=-0.44)$ and $\mathrm{DV}_{0.1}(\mathrm{r}=-0.57)$ and between $\mathrm{V} 100$ and DMV $(r=-0.84)$, viscosity $(r=-0.48)$, density $(r=-0.26)$, surface tension $(r=-0.40)$ and $D^{-1}(r=$ $-0.95)$. 
TABLE 2. Correlation among physical variables within the droplet spectrum analysis for all treatments.

\begin{tabular}{lccccccc}
\hline \multicolumn{1}{c}{ Variables } & $\mathrm{ST}^{1}$ & Density & Viscosity & DMV & V50 & V100 & $\mathrm{DV}_{0.1}$ \\
\hline $\mathrm{ST}^{1}$ & - & 0.15 & $0.53^{*}$ & $0.31^{*}$ & $-0.44^{*}$ & $-0.40^{*}$ & $0.41^{*}$ \\
Density & 0.15 & - & $0.31^{*}$ & $0.32^{*}$ & -0.02 & $-0.26^{*}$ & $0.25^{*}$ \\
Viscosity & $0.53^{*}$ & $0.31^{*}$ & - & $0.67^{*}$ & $-0.21^{*}$ & $-0.48^{*}$ & $0.50^{*}$ \\
DMV & $0.31^{*}$ & $0.32^{*}$ & $0.67^{*}$ & - & $-0.26^{*}$ & $-0.84^{*}$ & $0.86^{*}$ \\
V50 & $-0.44^{*}$ & -0.02 & $-0.21^{*}$ & $-0.26^{*}$ & - & $0.53^{*}$ & $-0.57^{*}$ \\
V100 & $-0.40^{*}$ & $-0.26^{*}$ & $-0.48^{*}$ & $-0.84^{*}$ & $0.53^{*}$ & - & $-0.95^{*}$ \\
DV $_{0.1}$ & $0.41^{*}$ & $0.25^{*}$ & $0.50^{*}$ & $0.86^{*}$ & $-0.57^{*}$ & $-0.95^{*}$ & -
\end{tabular}

* Correlation significant at 5\% probability $(\mathrm{p}<0.05) .{ }^{1} \mathrm{ST}-$ Surface Tension in $\mathrm{mN} \mathrm{m}^{-1}$; Density $\left(\mathrm{g} \mathrm{cm}^{-3}\right) ; \mathrm{Viscosity}(\mathrm{mPa} \mathrm{s}) ; \mathrm{DMV}$ $(\mu \mathrm{m})$ and $\mathrm{DV}_{0.1}(\mu \mathrm{m})$.

Relationships and interactions of the variables with the treatments and contributions of F1 and F2 factors are shown in Figure 2. There is a formation of four distinct groups, with adjuvant grouping or remoteness characterized by high or low values of the variables evaluated.

V100 was the variable that most influenced treatment variability, followed by V50. The T12 (Define $^{\circledR}-0.12 \%$ ) had the highest remoteness from other treatments, which was characterized by high values of viscosity, $\mathrm{DV}_{0.1}$ and $\mathrm{DMV}$. It was noted a greater influence of surface tension on T11 (Define $\left.^{\circledR}-0.06 \%\right)$, T26 (Nutrifix ${ }^{\circledR}-0.1 \%$ ) and T32 (Tac-Tic $\left.^{\circledR}-0.26 \%\right)$.

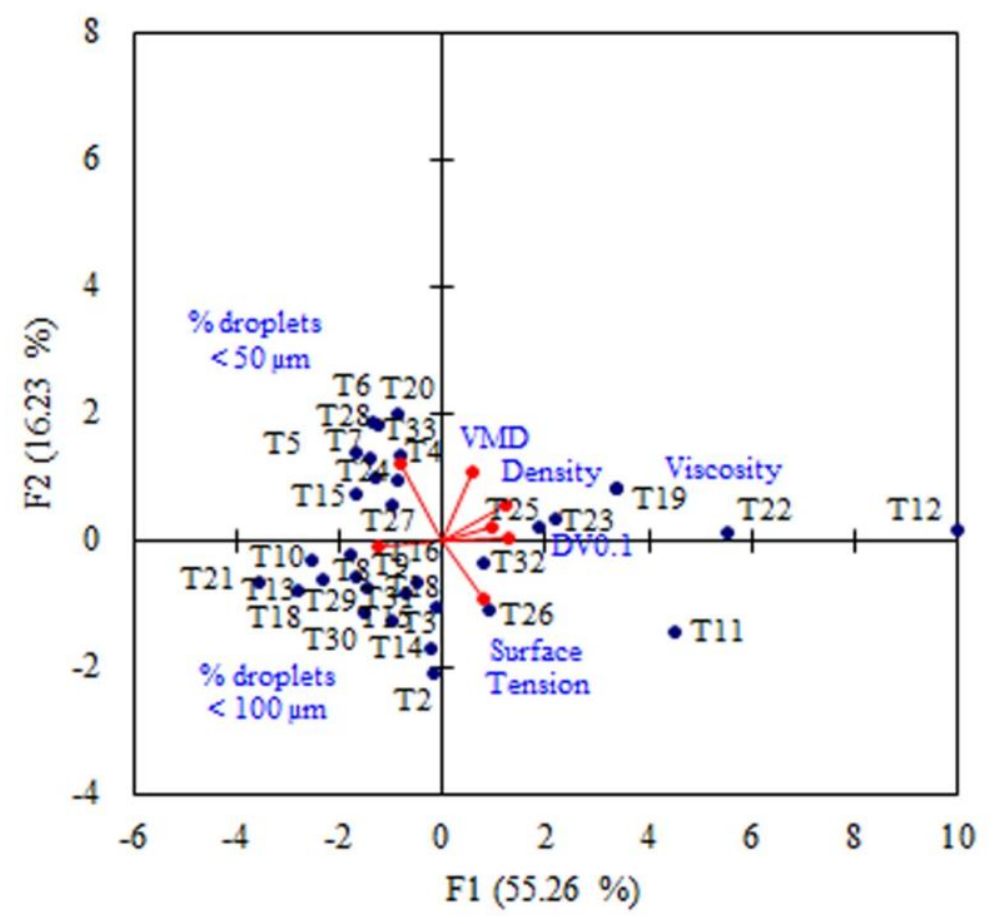

FIGURE 2. Graphics of the relationship between physical variables and droplet spectrum variables and interactions with treatments.

Figure 3 presents the principal component analysis of the variables, showing their relationships and contributions to F1 and F2. It is observed that all variability of the variables, with respect to their correlations among each other, was summed up in two factors that explain $71.49 \%$ all data variability. The $\mathrm{DV}_{0.1}(\mathrm{r}=0.90)$ and $\mathrm{DMV}(\mathrm{r}=0.85)$ provided the highest contributions 
within F1 and V50 ( $\mathrm{r}=-0.90)$ within F2. On the positive axis side are positively correlated with each other; and the closer the lines, the higher their correlation; moreover, by the left side are the variables that are negatively correlated with each other. It was noted nearest positive interactions among viscosity, $\mathrm{DV}_{0.1}$ and $\mathrm{DMV}$, and more remote relations with density. V50 and V100 had negative interactions, but under different magnitudes and they showed an inverse relationship with the other variables. This fact indicates that adjuvants altered physical and chemical properties of aqueous solutions at different magnitudes, depending on the used concentration.

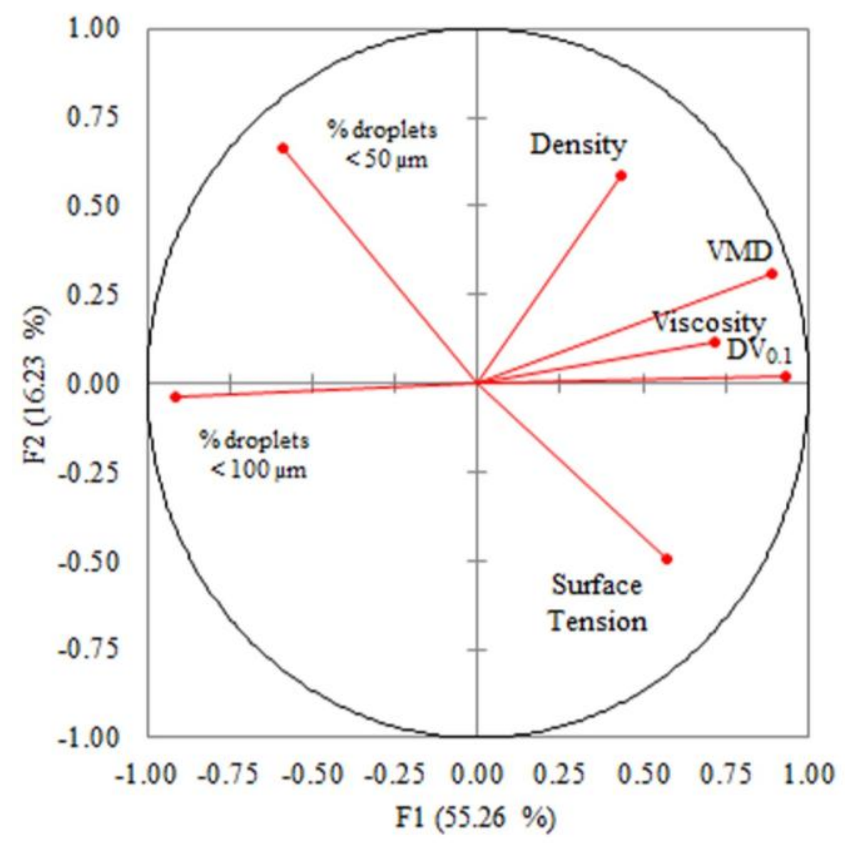

FIGURE 3. Principal component analysis (Factor 1 and Factor 2) of the variables and contribution within these factors for adjuvants at different concentrations.

Considering DMV and V100 as spectrum most related variables to drift, as seen in the graphical correlation of Figure 4. It was found in data clouds a negative correlation between drift and DMV, i.e., as DMV increases there is a reduction in drift values. For V100, there was a positive correlation, that is, insofar as it increases, drift potential also raises, indicating that using the adequate nozzle or adjuvants that reduce V100 can provide a lower drift risk. V100 range is easily carried by the wind, undergoing more intensively the weather phenomena. VAN DE ZANDE et al. (2008) suggested V100 as a parameter to select nozzle type, since V100 shows a linear relationship with drift, which may be understood through this study. The smaller V100 is, the lower the drift risk during application (CUNHA et al., 2010).

V100 showed improved correlation with all variables whether compared to V50. Therefore, this data was more suitable for correlation with factors affecting spray operations; and consequently, for assessing adjuvant quality. This increased compliance may be due to greater variability in the treatments provided by V50 and the magnitude of values, hindering the interaction with other variables. 

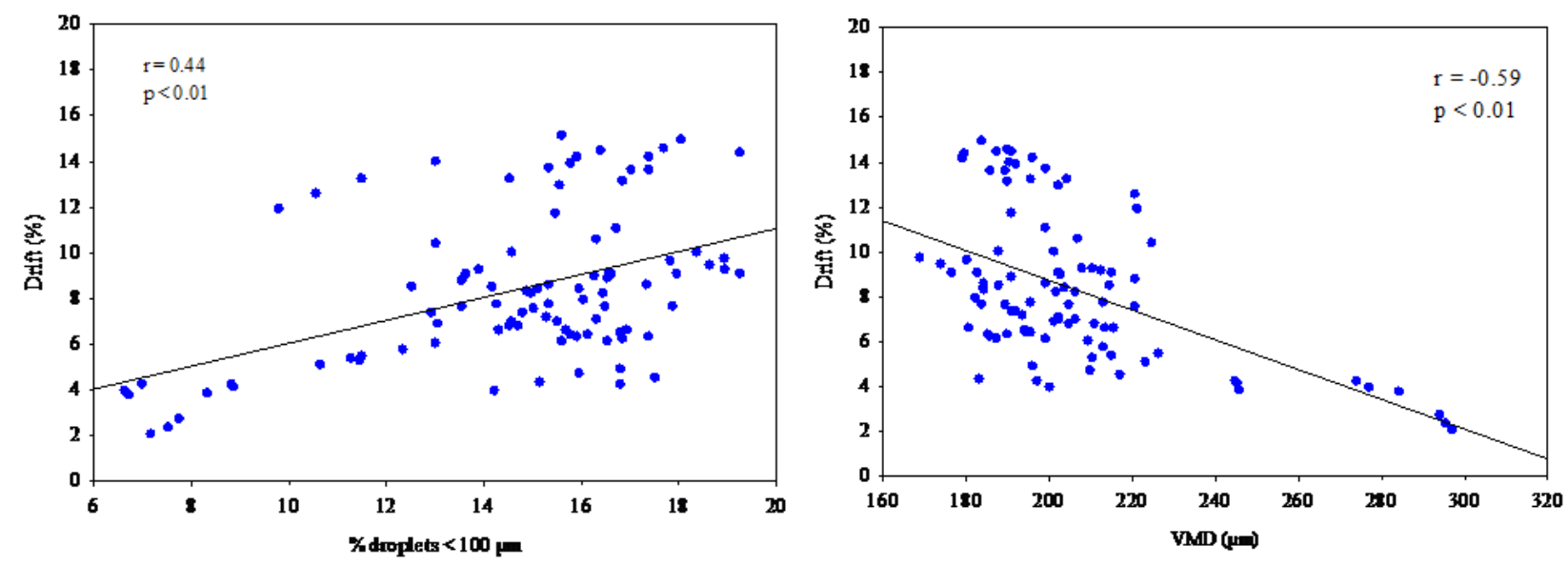

FIGURE 4. General correlation between drift and diameter of mean volume (DMV), percentage of droplets smaller than $100 \mu \mathrm{m}$ (V100) for the tested adjuvants and concentrations.

This research results contribute to standard methodology for simple, direct and independent assays, which would be able to prove effectiveness on drift reduction of a large number of adjuvants from Brazilian market.

\section{CONCLUSIONS}

The diameter of mean volume, percentage of droplets smaller than $100 \mu \mathrm{m}$ and viscosity have great influence on drift risk potential.

The evaluated characteristics and their respective determination methods are applicable on adjuvant assessment concerning drift risk potential.

\section{ACKNOWLEDGEMENTS}

The first author thanks the Conselho Nacional de Pesquisa - CNPq (Brazilian National Research Council) for PhD scholarship granted.

\section{REFERENCES}

BECK, B.; BRUSSELMAN, E.; NUYTTENS, D.; POLLET, S.; TEMMERMAN, F.;

STEURBAUT, W.; SPANOGHE, P. Improving foliar applications of entomopathogenic nematodes by selecting adjuvants and spray nozzles. Biocontrol Science and Technology, Oxford, v. 23, n.5, p. 508-520, 2013.

BUENO, M. R.; CUNHA, J. P. A. R.; ROMAN, R. A. A. Tamanho de gotas de pontas de pulverização em diferentes cond ições operacionais por meio da técnica de difração do raio laser. Engenharia Agrícola, Jaboticabal, v.34, n.5, p. 976-985, 2013.

FRITZ, B. K.; HOFFMANN, W. C.; KRUGER, G. R.; HENRY, R. S.; HEWITT, A.; CZACZYK, Z. Comparison of Drop Size Data from Ground and Aerial Application Nozzles at Three Testing Laboratories. Atomization and Sprays, Danbury, v.24, n.2, 2014.

CHECHETTO, R. G.; ANTUNIASSI, U. R.; MOTA, A. A. B.; CARVALHO, F. K.; ARRUDA E SILVA, A.; VILELA, C. M. Influência de pontas de pulverização e adjuvantes no potencial de redução de deriva em túnel de vento. Semina, Londrina, v. 34, n. 1, p. 37-46, 2013.

CUNHA, J. P. A. R.; BUENO, M. R.; FERREIRA, M. C. Espectro de gotas de pontas de pulverização com adjuvantes de uso agrícola. Planta Daninha, Viçosa, MG, v. 28, p. 1153-1158,

2010. 
GANDOLFO, M. A.; CHECHETTO, R. G.; CARVALHO, F. K.; GANDOLFO, U. D.; MORAES, E. D. Influência de pontas de pulverização e adjuvantes na deriva em caldas com glyphosate. Revista Ciência Agronômica, Fortaleza, v. 44, n. 3, p. 474-480, 2013.

GANDOLFO, M. A.; CHECHETTO, R. G.; CARVALHO, F. K.; GANDOLFO, U. D.; MORAES. Effect of working pressure at different spray nozzles on drift quantification in wind tunnel.

Engenharia Agrícola, Jaboticabal, v.34, n.1, 2014.

HAZEN, J. L. Adjuvants: terminology, classification, e chemistry. Weed Technology, Champaign, v. 14, p. 773-784, 2000.

McMULLAN, P. M. Utility adjuvants. Weed Technology, Champaign, v. 14, p. 792-797, 2000.

MOREIRA JÚNIOR, O; ANTUNIASSI, U. R. Construção e validação de um túnel de vento para ensaios de estimativa da deriva em pulverizações agrícolas. Revista Engenharia na Agricultura, Viçosa, MG, v.25, n.3, p.118-136. 2010.

MOTA, A. A. B. et al. Espectro de gotas da pulverização de herbicida com e sem a adição de adjuvante de calda. In: CONGRESSO BRASILEIRO DA CIÊNCIA DAS PLANTAS DANINHAS, 27., 2010, Ribeirão Preto. Anais... Ribeirão Preto: Sociedade Brasileira da Ciência das Plantas Daninhas, 2010.

NUYTTENS, D.; TAYLOR, W.; SCHAMPHELEIRE, M.; PIETER, V.; DEKEYSERET, D. Influence of nozzle type and size on drift potential by means of different wind tunnel evaluation methods. Biosystems Engineering, London, n. 3, p. 271-280, 2009.

OLIVEIRA, R. B.; ANTUNIASSI, U. R.; MOTA, A. A. B.; CHECHETTO, R. G. Potential of adjuvants to reduce drift in agricultural spraying. Engenharia Agrícola, Jaboticabal, v.34, n.5, p.986-992, 2013.

PENNER, D. Activator adjuvants. Weed technology, Champaign, v. 14, p. 785-791, 2000.

SCHAMPHELEIRE, M. D.; NUYTTENS, D.; BAETENS, K.; CORNELIS, W.; GABRIELS, D.; SPANOGHE, P. Effects on pesticide spray drift of the physicochemical properties of the sp ray liquid. Precision Agriculture, Bedford, v. 9, p. 1-12, 2008.

SPANOGHE, P.; SCHAMPHELEIRE, M.; MEEREN, P. V. D.; STEURBAUT, W. Influence of agricultural adjuvants on droplet spectra. Pesticide Management Science, Oxford, v. 64, p. 4-16, 2007.

VAN DE ZANDE, J. C.; HOLTERMAN, H. J.; WENNEKER, M. Nozzle classification for drift reduction in orchard spraying: identification of drift reduction class threshold nozzles. Agricultural Engineering International, Gainesville, v. 10, p. 12, 2008. 